\title{
Surveying seaweeds from the Ulvales and Fucales in the world's most frequently used artificial waterway, the Kiel Canal
}

https://doi.org/10.1515/bot-2018-0020

Received 28 February, 2018; accepted 28 August, 2018; online first 1 October, 2018

\begin{abstract}
The Kiel Canal is one of the world's most frequently used inland waterways and connects the SW Baltic Sea with the Wadden Sea. At the same time, the canal is a highly eutrophicated environment that is characterized by salinities that range from 3 to 16 . This brackish character could make the Kiel Canal an important stepping stone for the introductions of species into the inner Baltic Sea. It could also hinder the identification of native and introduced species, given the fact that salinity sometimes severely affects algal morphology. Here we report on a survey of introduced and native seaweed species in the canal, focusing on the dominant groups, which are Fucales and Ulvales. Of the Fucales, the introduced species Fucus evanescens was detected nearly exclusively inside the canal, while Fucus vesiculosus dominated rockweed communities directly outside the sluice gates. Morphological analysis and genetic barcoding distinguished three species of Ulvales, Ulva linza, Ulva intestinalis and an unknown and possibly introduced species of the genus Blidingia. Species distributions and - in the case of $U$. intestinalis - branching patterns were clearly affected by salinity, while thallus sizes appeared to be affected by the specific eutrophication status of sites within the canal.
\end{abstract}

Keywords: Fucus; green algae; invasive seaweeds; Kiel Canal; morphology.

\footnotetext{
*Corresponding author: Sophie Steinhagen, Marine Ecology Department, GEOMAR Helmholtz Centre for Ocean Research Kiel, Düsternbrooker Weg 20, Kiel 24105, Germany,

e-mail: ssteinhagen@geomar.de

Rolf Karez: State Agency for Agriculture, Environment and Rural

Areas, Schleswig-Holstein, Hamburger Chaussee 25, Flintbek 24220, Germany

Florian Weinberger: Marine Ecology Department, GEOMAR

Helmholtz Centre for Ocean Research Kiel, Düsternbrooker Weg 20, Kiel 24105, Germany
}

\section{Introduction}

Marine biological invasions are globally on the rise (Seebens et al. 2013, Tournadre 2014) and most introductions of seaweeds and other organisms into new habitats are related to ship traffic (Simberloff and Rejmanek 2011). Ports are also often hot spots of species introductions (Pollumaee et al. 2006) and, in particular, canals for seagoing vessels are important gateways for species introductions and genetic exchange (Minchin et al. 2006). The Kiel Canal is one of the two inland waterways that are most traveled by seagoing vessels worldwide (Gollasch and Rosenthal 2006) and it constitutes a bridge between two different ecozones - the brackish and non-tidal Baltic Sea in the East and the tidal and fully marine North Sea in the West. This waterway of about $100 \mathrm{~km}$ provides a more sheltered and shorter (by 400 nautical miles) transit between the North Sea and the Baltic Sea than the alternative route through the Skagerrak.

As a brackish inland sea that only developed after the last ice age, the Baltic Sea received most of its species inventory from the North Sea and few - if any - cases so far exist of documented genetic exchange through the Kiel Canal instead of the Skagerrak. The canal must nonetheless be expected to be a corridor for species invasions into the Baltic Sea. Salinity tolerant alien species could not only be passively transported through the canal as fouling organisms on ship hulls, but also be actively spread by colonizing the canal itself. To a water depth of approximately $2 \mathrm{~m}$, both shores of the canal are stabilized by packing of natural stones, which provides a substratum for algae and other sessile organisms.

As a habitat the Kiel Canal is characterized by a salinity gradient. The waterway is closed at both ends by sluice gates at Kiel-Holtenau (Baltic Sea) and Brunsbüttel (Elbe river estuary, which meets the North Sea) and, due to numerous inflows of surface and ground water into the canal and because this water is mainly released into the North Sea, salinity in the canal drops from approximately 16 at Kiel-Holtenau to about 1-3 at Brunsbüttel (Gollasch and Rosenthal 2006). Thus, the Kiel Canal offers approximately the same range of salinities as the whole Baltic Sea 
from the Kiel Bight to its innermost parts in the Gulf of Finland and the Bothnian Sea (Rönnbäck et al. 2007) - a circumstance that could increase the canal's potential as a stepping stone for species introductions into the inner Baltic Sea. Nevertheless, potential invaders have to be able to manage and tolerate the strong salinity fluctuations present, at least until they are able to settle in their preferred range.

Only few studies so far have recorded algae within the Kiel Canal (Brandt 1896, Hinkelmann and Schulz 1899, Arndt 1931/32, Aleem and Schulz 1952). After building operations finished in 1895 , the first algae to be observed were representatives of the former genus Ulva and several weeks later the former genus Enteromorpha was also established (Brandt 1896). Perennial algae like Fucus vesiculosus were first observed in 1899 (Hinkelmann and Schulz 1899). Approximately 15 years after the first enlargement of the canal in 1914, Arndt (1931/32) also observed $F$. vesiculosus Linnaeus at different locations in the eastern section of the canal, but dense populations were only present near the sluice gates in Kiel-Holtenau. Some decades later, Aleem and Schulz (1952) found no Fucus, as did Schütz (1963), who observed mostly species formerly placed in the genus Enteromorpha throughout the canal, in addition to some other brown and red algal taxa that became less frequent with decreasing salinity. Since the second enlargement of the canal in 1965, there have been no documented observations of its algal flora.

In the present study we aimed to detect algal bioinvaders within the Kiel Canal and to update the species inventory. We focused on dominant taxa and, in particular, on representatives of the orders Ulvales and Fucales. Members of the genus Ulva - that nowadays combines the former genera Enteromorpha (tubular species) and Ulva (sheet-like species) - can be found throughout the canal with many different morphologies, which could hint at the presence of cryptic introduced species. Ulva occurs in a wide range of environments worldwide and many of its members are characterized by an opportunistic life history strategy that may facilitate their introduction into new ecosystems (Baamonde et al. 2007, Mineur et al. 2008, Wolf et al. 2012). At the same time, the taxonomy of Ulva and related species is notoriously difficult. An identification solely based on morphological traits often leads to the misinterpretation of different Ulva morphotypes as different species (Tan et al. 1999, Hayden et al. 2003). Aberrant morphotypes of certain Ulva species were commonly recorded in eutrophicated habitats or in environments with strongly fluctuating abiotic factors like salinity (Dangeard 1957, Burrows 1959, Reed and Russell 1978, Blomster et al. 2002). A remarkable example is Ulva intestinalis
Linnaeus. It characteristically exhibits unbranched, tubular thalli (Linnaeus 1753) but monostromatic thalli of this species were found in highly eutrophicated waterbodies (Blomster et al. 2002) and so called "bottle-brush" morphotypes of $U$. intestinalis have been observed under controlled laboratory conditions in relation to salinity change and also in media with extreme salinities (Reed and Russell 1978). Under natural conditions, branched, proliferous specimens of $U$. intestinalis have been predominantly recorded in brackish habitats, such as the Baltic Sea (Bliding 1963) but, due to the overlap in morphology with other species, the exact identification and analysis of the morphotype distribution in different environments was largely hampered, as it required genetic information (Leskinen et al. 2004). Similar morphological variability can also be observed in Ulva linza Linnaeus, which comprises sheet-like unbranched thalli, as well as variously branched tubular morphologies that were formerly described as distinct species (e.g. Enteromorpha ahlneriana Bliding, Brodie et al. 2007). However, the spatial distribution patterns of morphologies concomitant with genetic species validation have rarely been investigated along natural gradients of salinity or other environmental factors and the above described findings were based on single observations.

Using a combined approach of genetic identification via DNA barcoding and classical morphological identification, we were able to assess the taxonomic and morphological diversity of Ulvales within the Kiel Canal. We could also link the distribution of different morphological forms to salinity and nutrient gradients that are present in the canal. Moreover, we analyzed the current distribution of native and non-native Fucus species.

\section{Materials and methods}

\section{Field observations and sample preparation}

In total, 16 sites, mostly separated by no more than $10 \mathrm{~km}$, were visited to obtain samples of Ulvales in all parts of the canal (Figure 1). Sampling took place in May 2016 and in winter 2017-2018. Specimens representing all morphologies found were collected at each sampling site and preserved in a freezer. For species identification, representative epiphyte-free small thalli or thallus sections of $1 \times 1 \mathrm{~cm}$ were dried in silica gel for subsequent DNA extraction. After DNA barcoding, 10 specimens of each species from each sampling site were defrosted and examined for their branching pattern and thallus height. Examination 
A

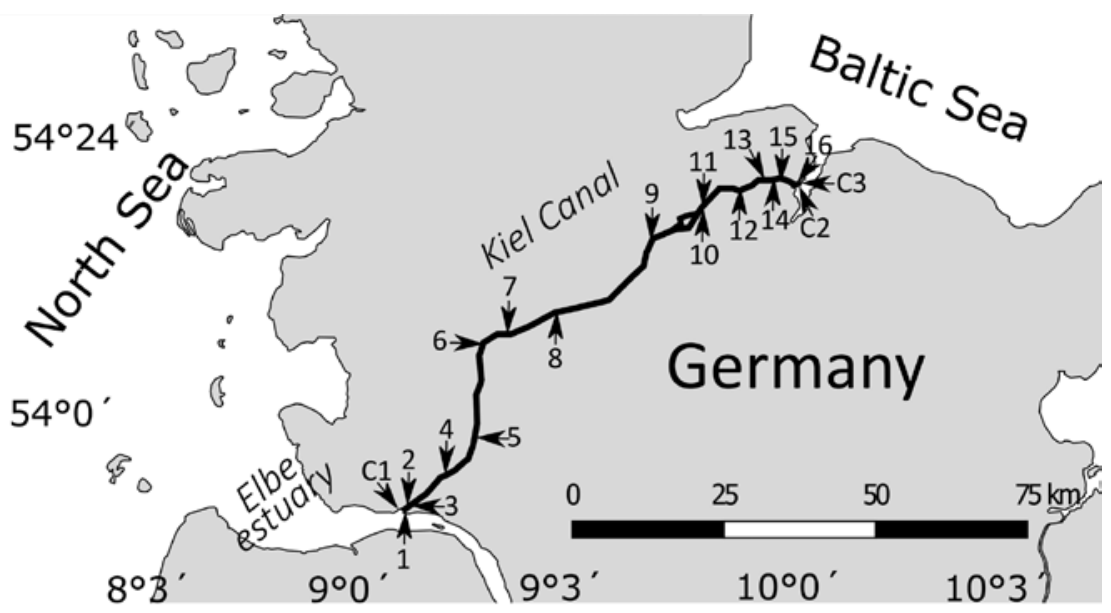

B

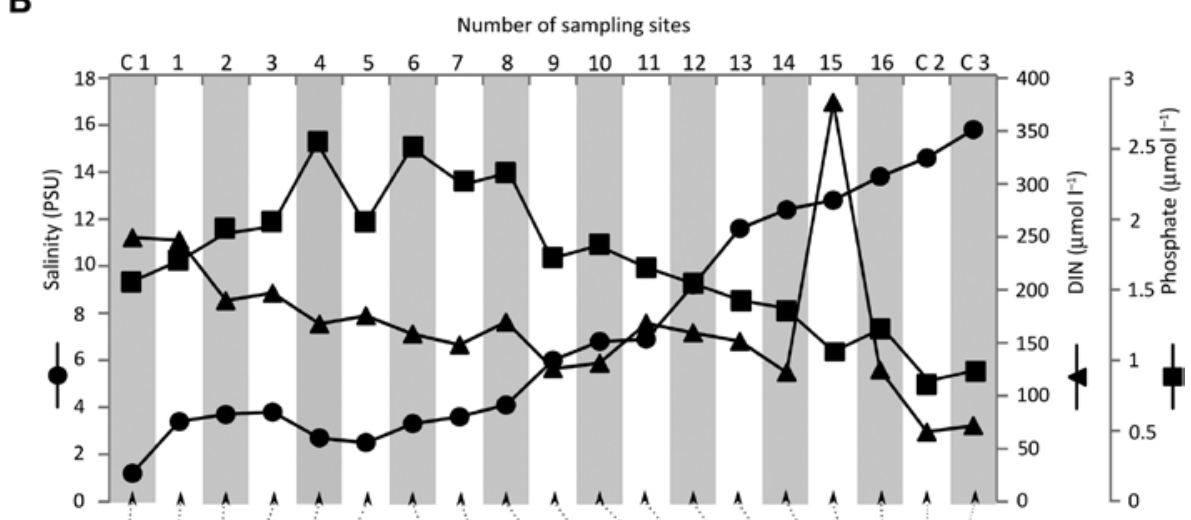

C

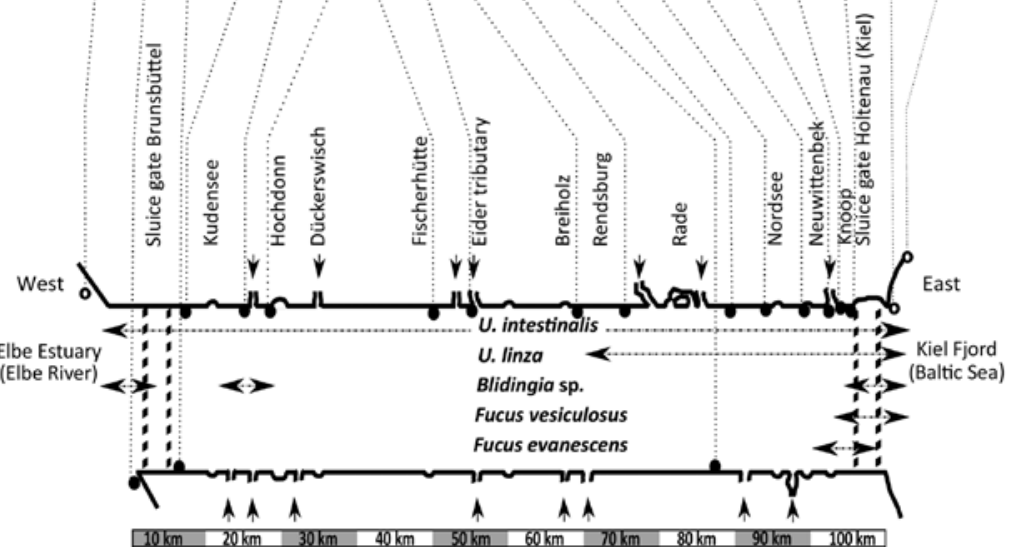

Figure 1: Map of the study area and distribution of chemical parameters and detected species.

(A) Map of the Kiel Canal (black line) in Northern Germany with location of sampling sites (arrowheads). (B) Salinity, dissolved inorganic nitrogen (DIN) and phosphate at the sampling sites 1-16 and the reference sites C1-C3 outside the canal, where only water parameters were measured. (C) Spatial distribution of Ulvales and Fucus species within the Kiel Canal. Arrows indicate major inflows of freshwater, names refer to larger towns or regions to facilitate orientation.

of branching was carried out carefully to discriminate between true branches and possible epiphytism. During the May sampling, salinity was measured at each site. In February 2018 - when algal and plant biomass in the canal was at its minimum - 20-ml water samples were collected in duplicate at all sites, including three control sites outside the canal (two in the Kiel Fjord and one in the Elbe estuary) for an estimation of the eutrophication status. Water samples were filtered through cellulose acetate filters with a pore size of $0.2 \mu \mathrm{m}$ and immediately preserved at $-20^{\circ} \mathrm{C}$. Dissolved inorganic nitrogen (DIN $\left[\mathrm{NH}_{4}\right.$, $\left.\left.\mathrm{NO}_{2}, \mathrm{NO}_{3}\right]\right)$ and phosphate $\left(\mathrm{PO}_{4}\right)$, were measured, using an 
automated wet chemistry analyzer (San ${ }^{++}$, Skalar Analytical B.V., Breda/Netherlands). For full collection data for all sites see Supplementary Table S1. The distribution of Fucus species along the canal was repeatedly monitored at different seasons between 2016 and 2018, in order to observe reproductive structures and the development of other morphological features that are relevant for species identification (Schueller and Peters 1994).

\section{Molecular biology}

DNA was extracted using the Invisorb Spin Plant Mini Kit (Stratec, Birkenfeld, Germany), following the manufacturer's protocol. For DNA barcoding the plastid-encoded elongation factor tufA was amplified by PCR, using the primers tufGF4 (Saunders and Kucera 2010) and tufAR (Famà et al. 2002) and the following temperature profile: an initial denaturation step $\left(94^{\circ} \mathrm{C}, 4 \mathrm{~min}\right)$, followed by 38 cycles of denaturation $\left(94^{\circ} \mathrm{C}, 1 \mathrm{~min}\right)$, annealing $\left(55^{\circ} \mathrm{C}\right.$, $30 \mathrm{~s}$ ), and extension $\left(72^{\circ} \mathrm{C}, 1 \mathrm{~min}\right)$, with a final extension phase of $7 \mathrm{~min}$ at $72^{\circ} \mathrm{C}$. Composition and concentration of the single ingredients of the Master Mix were according to the manufacturer's protocol for Phusion HighFidelity DNA polymerase (Thermo Fisher Scientific, MA, USA). Subsequent Sanger sequencing was provided by GATC biotech (Konstanz, Germany). Merging of forward and reverse sequences and further editing was done in Sequencher (v. 4.1.4, Gene Codes Corporation, Ann Arbor, MI, USA). Obtained sequences were stored in GenBank (accession numbers: MG797644-MG797657). Reference sequences retrieved from GenBank were included in this alignment and two sequences of Urospora species were chosen as an outgroup (HQ610440 and HQ610441). For phylogenetic analysis of the dataset a maximum likelihood approach was chosen. The optimal substitution model was calculated with the MrModeltest version 2.2. software (Nylander 2004) and was found to be GTR $+\mathrm{G}+\mathrm{I}$. Maximum likelihood analyses were carried out in RAxML version 8 (Stamatakis 2014) and the calculated best fit substitution model was applied with 1000 bootstrap iterations. On the basis of the genetic data, species affiliations and their respective distribution within Kiel Canal were determined.

\section{Regression analysis}

To determine the potential effect of environmental variables (salinity, dissolved inorganic nitrogen and phosphate) and their interactions on the abundance of branching and thallus height in Ulva species, regression models were stepwise developed, using the STEP procedure implemented in the R software package (R Development Core Team 2014). Briefly, this procedure successively eliminates interactions and variables from an original full model and uses the Akaike Information Criterion (AIC) to identify the least complex submodel that still has comparable explanatory power as the full model.

\section{Results}

At 16 sites within and three additional control sites outside the Kiel Canal (Figure 1A-C), measurements of salinity revealed a successive decrease from 15.8 outside the sluice gates of Kiel-Holtenau to 1.2 outside the sluice gates of Brunsbüttel. In contrast, DIN and phosphate tended to increase from East to West (Figure 1B, Supplementary Table S1). With the exception of one site (15), concentrations of DIN were between those observed at the control sites in the Baltic Sea and the Elbe river estuary. Already at the sluice gate in Kiel-Holtenau, the concentration of DIN was almost twice as high $\left(124.41 \mu \mathrm{mol} \mathrm{l}^{-1}\right)$ as at the adjacent control site in the Kiel fjord $\left(65.76 \mu \mathrm{mol} \mathrm{l}^{-1}\right)$. A similar increase from the fjord $\left(0.84 \mu \mathrm{mol}^{-1}\right)$ to the canal

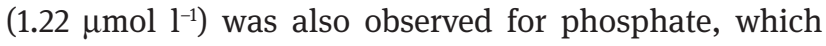
reached its maximum at some inland sites in the Western section of the canal.

As indicated in Figure 1C, the largest algal species diversity was found in the eastern part of the Kiel Canal, where it borders the Baltic Sea. Only Ulva intestinalis was present throughout the wholelength of the canal. Ulvalinza was restricted in its distribution to sites with a minimum salinity of six and was not found below this threshold. In addition, a Blidingia species was found at three locations (sites 1, 4, 16) through the length of the canal and no distinct distribution pattern could be observed. All three of these species were found attached and never drifting. Both Ulva species grew in the upper sublittoral and lower supralittoral zone, directly below and at the water surface. In contrast, the Blidingia species was restricted to the upper supralittoral, where it was only reached by waves generated by vessels. Two different Fucus species were detected in the canal. As in many other sites at the Baltic Sea, Fucus vesiculosus is a main component of the macrophytobenthos communities in the Kiel Fjord and it also forms dense stands directly outside of the sluice gates at Kiel-Holtenau. However, we found no evidence that $F$. vesiculosus penetrates more than $500-800 \mathrm{~m}$ into the canal. The distribution of Fucus evanescens C. Agardh, 
in contrast, extends about $8 \mathrm{~km}$ from Kiel-Holtenau until the salinity drops below 12.5 around Neuwittenbek (Figure $1 \mathrm{~B}-\mathrm{C})$. Interestingly, F. evanescens was not present directly outside the sluice gates and its closest known stand in the Kiel Fjord is at a distance of $2.9 \mathrm{~km}$.

All of the examined samples of Ulva sensu lato were processed genetically to ensure exact species identification and to test the genetic separation of morphologically distinct specimens. The partial alignment of the tufA sequences comprised 777 base pairs. The maximum likelihood tree obtained from the analysis of representative specimens (Figure 2) supports the genus Ulva as a monophyletic clade and the genus Blidingia as a sister group to it. Whereas the two Ulva species could be resolved with sequence references from GenBank in the phylogenetic analysis and showed the highest similarities with Ulva linza and Ulva intestinalis, the sequences of Blidingia fell unequivocally in a well-supported cluster that did not match with any sequences that have been published. Within the phylogenetic analysis, both clades of $U$. intestinalis and $U$. linza contain specimens of branched and unbranched morphology. However, these morphological

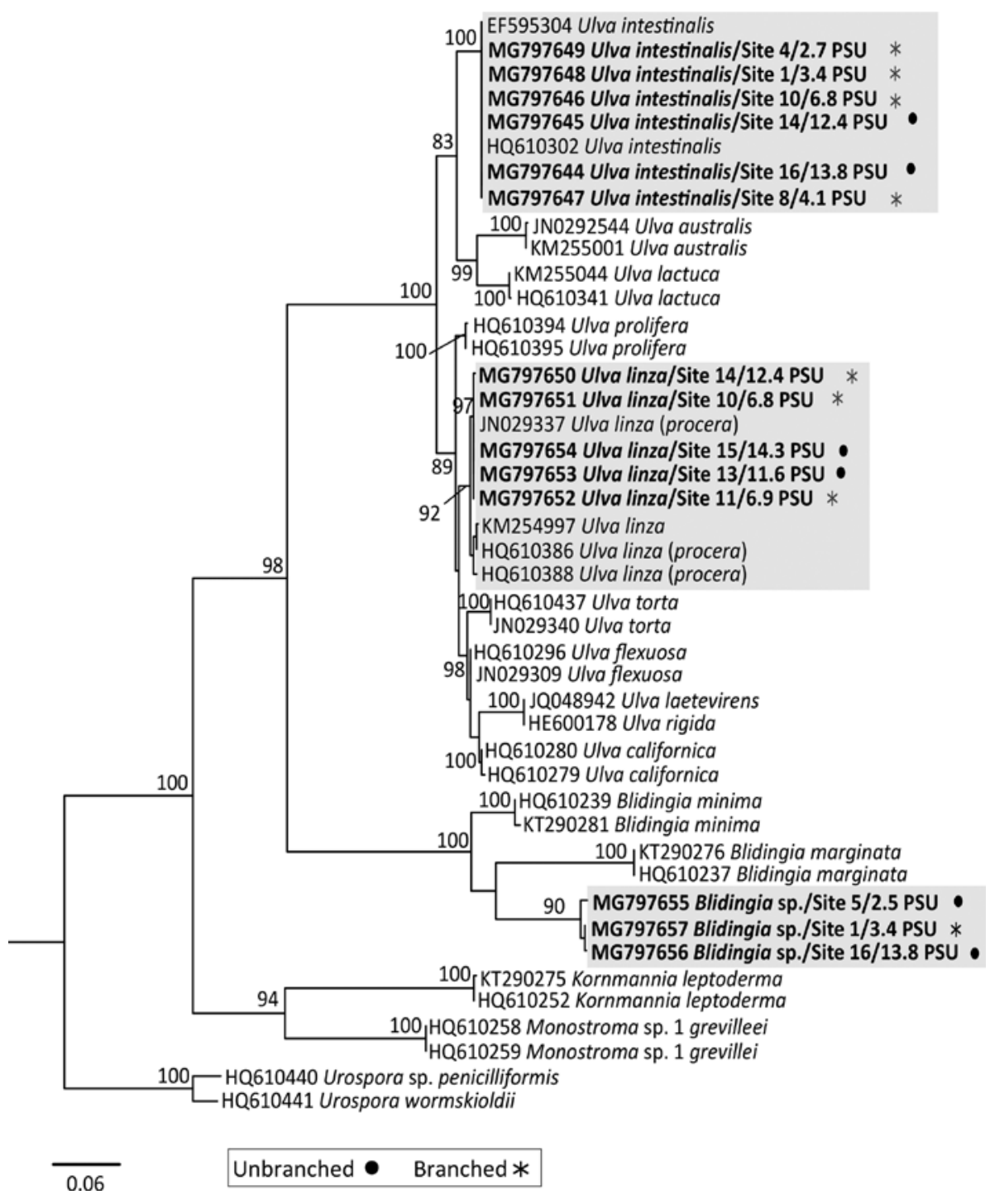

Figure 2: Maximum likelihood tree inferred from tufA sequences, representing Ulvales species and their respective morphotypes, present in the Kiel Canal.

Numbers at nodes refer to bootstrap values $>70$. Branch lengths are drawn proportionally to the amount of sequence change and GenBank accession numbers are given for all included samples. Clades containing specimens investigated within this study are highlighted in gray. Sample sites and their recorded salinity within the Kiel Canal are indicated. Samples marked with a solid circle are of unbranched morphology, those labeled with an asterisk are branched. 
differences are not reflected in a genetic separation and the monophyletic origin of both clades receives support from high bootstrap support values (Figure 2). Interestingly, our phylogenetic analysis revealed two subclades of $U$. linza. One of these included all samples from the Kiel Canal and a sequence from Tasmania (JN029337), while the other comprised samples from different locations in the North Atlantic (KM254997, HQ610386, HQ610388).

Specimens of Ulva intestinalis growing in the eastern part of the Kiel Canal clearly corresponded with the typical unbranched form of $U$. intestinalis (Figure 3A-B). In very few specimens branching was observed within the rhizoidal zone or at the very base of a thallus. From East to West, the occurrence of branched specimens gradually increased (Figure 3C-D). Below a salinity threshold of 4.1 branched specimens of $U$. intestinalis were dominantly found whereas unbranched specimens were rare (Figure 3D-F). Thalli of this branched morphotype were commonly of compact growth and their maximal thallus length was between 0.5 and $4 \mathrm{~cm}$. In contrast, specimens found in higher salinities exhibited thallus lengths of 8-19 $\mathrm{cm}$. Altogether, the gradual increase in branching of $U$. intestinalis correlated with a decrease in thallus size, and the number of highly branched specimens with reduced thallus size visibly increased from Holtenau to Brunsbüttel (Figure 4A).

Highly branched forms of Ulva linza were also observed (Figure 5A, C). However, even though the unbranched phenotype prevailed, the branched phenotype was also observed at all sites where $U$. linza was present (Figure 5B, D). Correspondingly, no clear correlation of branching and thallus size or a gradual change in the distribution of morphotypes along the canal was observed for this species (Figure 4B).

Stepwise regression model selection confirmed the impact of salinity on the morphology of Ulva intestinalis. The selected model for the number of branches of $U$. intestinalis retained only salinity as the best predictor of the observed variability, while concentrations of environmental DIN and phosphate were not selected (Table 1). Also the best fitting model for prediction of the overall thallus height of $U$. intestinalis contained salinity, as well as phosphate concentration and the interaction of salinity and phosphate concentration. Only the interaction of both variables had significant influences on the thallus height. Particularly short thalli were observed at sites with relatively low salinity in combination with relatively high phosphate concentration. Nutrient supply was also identified as a relevant predictor of thallus height in Ulva linza. The best explanatory model selected salinity, DIN concentration and the interaction of phosphate concentration and DIN concentration as significant predictors (Table 1). Particularly long thalli were observed when phosphate concentrations were relatively high, but DIN concentrations were low. In addition, thallus length of $U$. linza was significantly suppressed by low salinity. In contrast, no significant regression model was detected that could predict the number of branches in U. linza. Due to the scattered appearance of Blidingia sp. at only three sampling sites, its morphological variability could not be analyzed further.

\section{Discussion}

Altogether, our expectation of a relatively large number of cryptic Ulvales within the Kiel Canal was not confirmed. In comparison to surrounding ecosystems like the German Wadden Sea and the Baltic Sea (Bartsch and Kuhlenkamp 2000, Schories et al. 2009), the diversity of Ulvales inside the Kiel Canal is rather small. Based on barcoding of the tufA gene region, only three species were delineated. Most of the samples examined could be unambiguously identified as Ulva intestinalis and Ulva linza, while the third species appears within the Blidingia cluster of our phylogenetic analysis and does not match any existing GenBank entries. The phylogenetic analysis separates this clade with bootstrap support values of 100 from Blidingia minima (Nägli ex Kützing) Kylin and Blidingia marginata (J. Agardh) P.J.L. Dangeard ex Bliding, the only two species of the genus that were so far recorded in the Baltic Sea (Nielsen et al. 1995). Two other Blidingia species have been reported in the North Sea (Bartsch and Kuhlenkamp 2000, Schories et al. 2009). Blidingia chadefaudii (Feldmann) Bliding was observed on many European Atlantic coasts and also on the German North Sea island Helgoland, whereas Blidingia subsalsa (Kjellman) Kornmann et Sahling ex Scagel was reported from Helgoland and the North Frisian Wadden Sea (Bartsch and Kuhlenkamp 2000, Schories et al. 2009). For both species no genetic reference data are available and an unambiguous identification based upon morphological criteria alone seems problematic. A thickened inner wall that is present in transverse sections has been suggested as a morphological identification criterion for $B$. chadefaudii, but has not been observed in North Sea populations from Helgoland (Kornmann and Sahling 1978). Blidingia subsalsa was distinguished from other Blidingia species in that it is branched (Burrows 1991) but, of the specimens observed by us in the Kiel Canal, some were branched and most were unbranched. Available descriptions of $B$. chadefaudii 

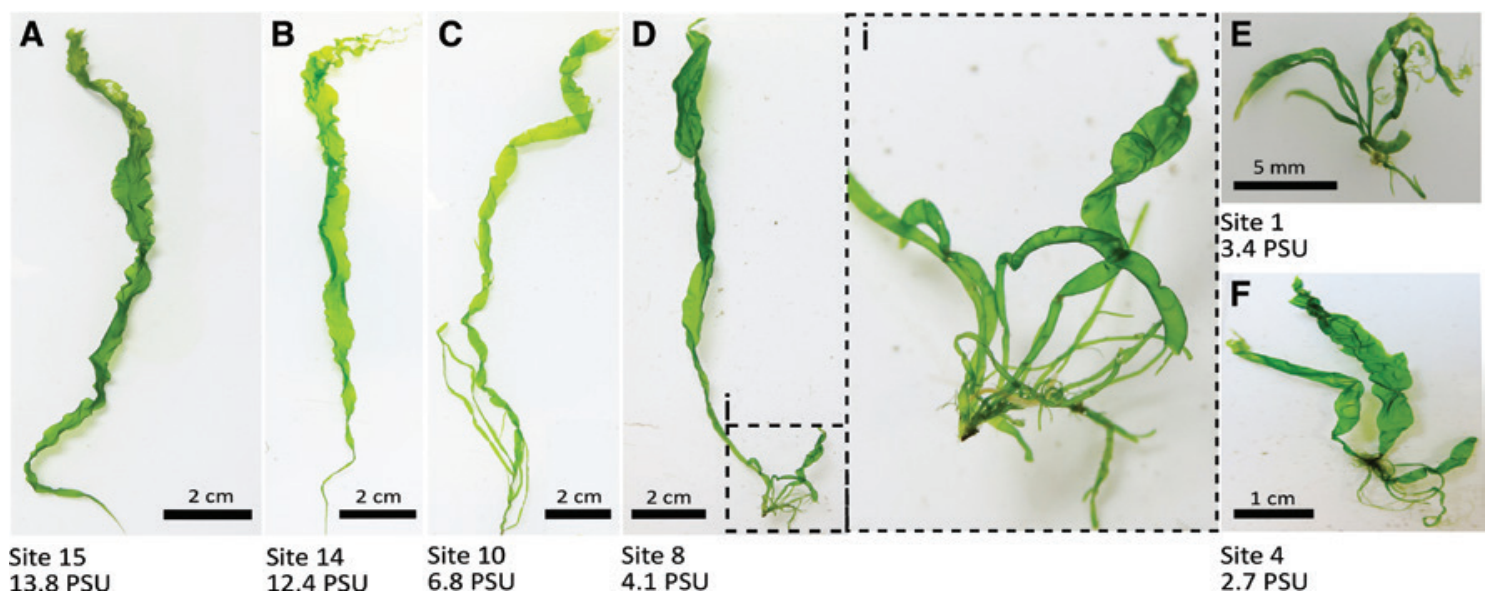

Figure 3: Morphology of material genetically identified as Ulva intestinalis collected from the Kiel Canal.

Sampling sites with salinity recorded during collection are indicated. (A-B) Display the typical unbranched morphotype of $U$. intestinalis, whereas some specimens only exhibited branches at the thallus base ( $C-D)$; $i$ is a close-up of thallus base of $D$. (E-F) Display branched forms of $U$. intestinalis with reduced thallus size encountered at low salinity sampling sites.
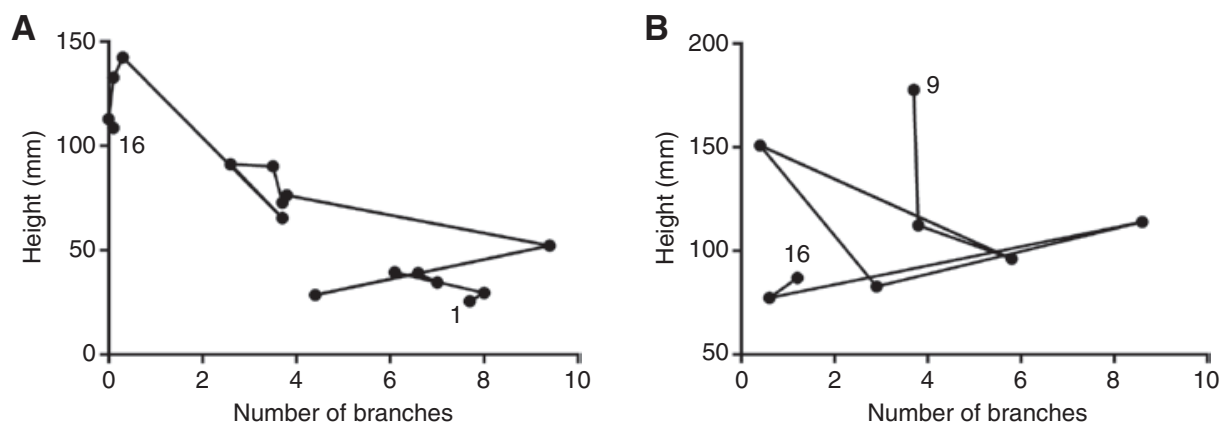

Figure 4: Number of branches versus thallus height for Ulva intestinalis (A) and Ulva linza (B) collected in the Kiel Canal.

Numbers indicate sampling sites and lines connect data in the sequence of sites along the canal (sites 1-16 for $U$. intestinalis and 9-16 for U. linza; compare Figure 1C).

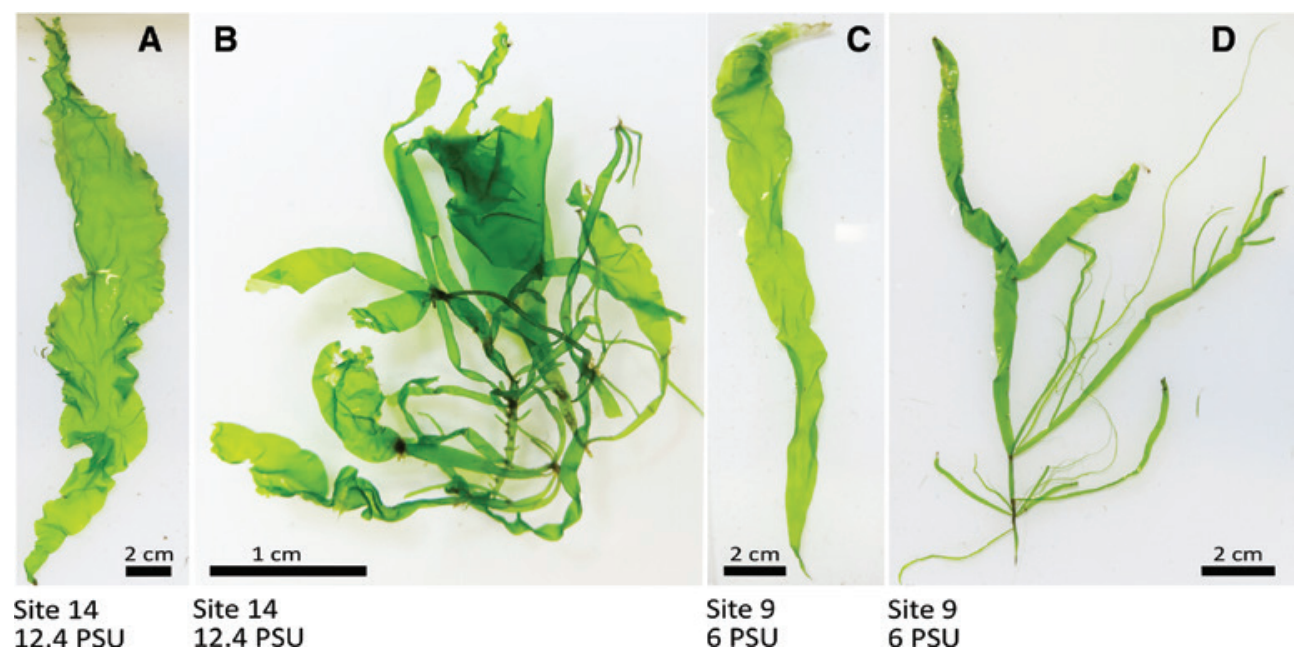

Figure 5: Morphology of material genetically identified as Ulva linza collected from the Kiel Canal.

Sampling sites with salinity recorded during collection are indicated. Branched and unbranched morphotypes of $U$. linza observed at two sampling sites with relatively high (A-B) and low (C-D) salinity are shown. 
Table 1: Details of stepwise regression analyses used to model the number of branches and overall thallus height of Ulva intestinalis and $U$. linza specimens collected in the Kiel Canal.

\begin{tabular}{llrrrrrrrr}
\hline & Effect & Adjusted $\mathrm{r}^{2}$ & p-Value & Salinity & PO $_{4}$ & DIN & Salinity: PO $_{4}$ & Salinity: DIN & PO $_{4}:$ DIN \\
\hline U. intestinalis & Branch number & 0.2613 & $<0.0001$ & $<0.0001$ & - & - & - & - \\
& Thallus height & 0.4354 & $<0.0001$ & 0.46363 & 0.27128 & - & 0.00198 & - \\
\multirow{2}{*}{ U. linza } & Branch number & 0.04257 & 0.189 & & & & & - \\
& Thallus height & 0.2914 & $<0.0004$ & 0.04127 & 0.34603 & 0.00517 & 0.17324 & - & 0.00132 \\
\hline
\end{tabular}

In each model all measured predictors [salinity, phosphate, dissolved inorganic nitrogen (DIN)] and their combinations were included and the model with the lowest Akaike Information Criterion (AIC) after stepwise reduction was selected. Adjusted $\mathrm{r}^{2}$ and $\mathrm{p}$-value of the selected model and $p$-values of factors and interactions included in the selected model are given. Significant values are indicated in gray.

and $B$. subsalsa are for material collected in fully marine environments. However, our samples were detected at low (14-16) or very low (3-4) salinities, which could cause divergent morphologies, as with Ulva intestinalis in the present study. Further, the capacity of the newly discovered Blidingia sp. to grow at low salinities should allow it to spread to most parts of the inner Baltic Sea and currently confusion with Blidingia minima - which was reported from the Gulf of Finland and the southern Bothnian Sea - cannot be excluded. To achieve nomenclatural certainty, lifecycle observations and genetic comparisons of a larger sample set need to be conducted, but this was not the objective of our study.

Considerable morphological plasticity was observed in both Ulva species that are present in the Kiel Canal. However, as did Aleem and Schulz (1952) and Schütz (1963), we only found tubular representatives and no blade-shaped thalli like those observed by Brandt (1896) shortly after the construction of the canal. This variability appeared to be affected by salinity especially in Ulva intestinalis. A certain plasticity of $U$. intestinalis has been observed before and the impact of salinity on the morphology of this species has been discussed (Bliding 1963, Reed and Russell 1978, Blomster et al. 1998). Reed and Russell (1978) observed that the typical unbranched morphology of U.intestinalis (Linnaeus 1753) developed from cut thallus pieces even at salinities below eight. The authors therefore suggested that extreme changes of salinity, rather than a specific salinity, induce branching in $U$. intestinalis. In contrast, our study of thalli that developed under natural conditions confirms that highly branched specimens of $U$. intestinalis dominate at low salinities. We observed a salinity gradient within the Kiel Canal that corresponds very well with previous observations (Gollasch and Rosenthal 2006), which strongly suggests that salinities at different sampling sites must be relatively stable. A gradual increase of branching was observed with decreasing salinity and microscopic observation confirmed that the branches were true and not a result of epiphytism of multiple individuals upon each other (data not shown). Branched individuals largely dominated at salinities below 4.1. This morphological variation was not reflected by genetic variation within the tufA marker gene. These findings agree with previous studies that compared the ITS barcode marker of specimens of different morphologies (De Silva and Burrows 1973, Blomster et al. 1998). Strong morphological plasticity was also observed in Ulva linza. However, our observations do not support an effect of salinity or the overall eutrophication status of the environment on branching patterns in this species.

In contrast, the maximal thallus length of both Ulva species was affected interactively by salinity and the eutrophication status. Because the Kiel Canal is an artificial environment, its eutrophication status is not regularly monitored and long-term data are lacking. However, our measurements of phosphate and DIN in winter are similar to winter conditions in the surrounding lakes, which are also highly eutrophicated (LLUR 2014). Likewise, our finding of lower nutrient loads in the Kiel Fjord and even higher nutrient loads in the Elbe estuary corresponds with long-term measurements (LLUR 2014). These suggest that gradients of phosphate and nitrogen availability exist within the canal (Figure 1) that probably result from the fact that nutrient-dense freshwater input is mostly discharged in a westerly direction (Gollasch and Rosenthal 2006). Although salinity affected the thallus height in both Ulva linza and Ulva intestinalis, nutrient concentrations had a comparable or even stronger impact (Table 1). Given the relatively limited database, the impact of single nutrients should be interpreted with caution. However, we suggest that salinity alone can predict branching patterns in U. intestinalis, while indicators of the eutrophication status improve the prediction of thallus size in both species considerably.

Notably, all specimens genetically identified as Ulva linza were more closely related with a sequence which 
originates from Tasmania (JN029337) than with other samples collected in the North Atlantic, for example in New Brunswick, Canada. This could indicate that the specimens found of $U$. linza represent an invasive genotype, though it remains unclear where its region of origin is.

We observed Fucus in the eastern parts of the canal at salinities of 12.5 or more. These observations were in agreement with the previous studies of Arndt (1931/32) and Hinkelmann and Schulz (1899), but contrast with the findings of Aleem and Schulz (1952) and Schütz (1963). However, nowadays only the introduced species Fucus evanescens occurs abundantly within the canal, while dense stands of the native Fucus vesiculosus dominate directly outside the sluice gates at Kiel-Holtenau. Under controlled conditions the reproduction of $F$. evanescens fails at salinities lower than 10 (Wikström et al. 2002), which approximately corresponds with the distribution boundary of the species in the canal that was observed within this study. In contrast, $F$. vesiculosus is generally able to settle at salinities as low as four (Rönnbäck et al. 2007). For this reason, its absence from the canal cannot be explained by unsuitable salinity. Interestingly, Bokn et al. (1992) observed a decline of native Fucus species after the severe eutrophication of the inner Oslo Fjord in the 1970s, while F. evanescens flourished after this increased nutrient supply. Reduction of nutrient inputs resulted in a reversal of these developments in the late 1980s, i.e. a recovery of native Fucus species and a decline of $F$. evanescens occurred (Bokn et al. 1992). The rapid spread of $F$. evanescens within Kiel Bight after its introduction was also assumed to be facilitated by the decline of $F$. vesiculosus and Fucus serratus in earlier years (Schueller and Peters 1994), which was primarily due to eutrophication (Vogt and Schramm 1991). Hence, the evident decline and the final absence of F. vesiculosus from the canal during the middle of the 20th century (Aleem and Schulz 1952) possibly resulted from the onset of eutrophication in the Kiel Canal, which is still at a much higher level than in most coastal environments of the Baltic Sea.

In conclusion, the Kiel Canal currently appears to be a suitable habitat for Fucus evanescens and it harbors an unidentified species of Blidingia that may spread into the inner Baltic Sea, due to its capacity for growth at low salinities. The canal also harbors a genotype of Ulva linza that was so far only detected in Tasmania, which could suggest a certain invasion potential. Nonetheless, the current abundance of non-native seaweeds in the canal appears to be moderate. Species such as Gracilaria vermiculophylla (Ohmi) Papenfuss and Dasya baillouviana (S.G. Gmelin) Montagne, which were recently introduced into the SW Baltic and are tolerant of low salinities, have not been detected in the canal so far (G. Bock, pers. comm.). Moreover, the high variability of Ulva morphologies in the canal is not due to a presence of multiple and possibly introduced cryptic species, but results from an adaptation of only two species to different salinity and nutrient regimes. Because gross morphological characters like branching are only partly diagnostic for certain Ulva species, and environmental factors may influence morphology, exact species identification within the genus based upon morphological patterns is still difficult. Obviously, the identification method of choice, especially in environments with variable salinity, should be a combined approach of molecular and morphological identification criteria.

Acknowledgments: We greatly appreciate the support of Bente Gardeler in nutrient analysis.

\section{References}

Aleem, A.A. and E. Schulz. 1952. Über Zonierung von Algengemeinschaften (Ökologische Untersuchungen im Nord-Ostsee-Kanal, I.). Kieler Meeresforschungen 9: 70-76.

Arndt, W. 1931/32. Die Tierwelt des Nordostseekanals und ihr Lebensraum. Der Naturforscher 8: 113-118.

Baamonde, S., I. Baspino, R. Barreiro and J. Cremades. 2007. Is the cryptic alien seaweed Ulva pertusa (Ulvales, Chlorophyta) widely distributed along European Atlantic coasts? Bot. Mar. 50: 267-274.

Bartsch, I. and R. Kuhlenkamp. 2000. The marine macroalgae of Helgoland (North Sea): an annotated list of records between 1845 and 1999. Helgol. Mar. Res. 54: 160-189.

Bliding, C. 1963. A critical survey of European taxa in Ulvales, Part I. Capsosiphon, Percursaria, Blidingia, Enteromorpha. Opera Bot. 8: 1-160.

Blomster, J., C.A. Maggs and M.J. Stanhope. 1998. Molecular and morphological analysis of Enteromorpha intestinalis and E. compressa (Chlorophyta) in the British Isles. J. Phycol. 34: 319-340.

Blomster, J., S. Back, D.P. Fewer, M. Kiirikki, A. Lehvo, C.A. Maggs and M.J. Stanhope. 2002. Novel morphology in Enteromorpha (Ulvophyceae) forming green tides. Am. J. Bot. 89: 1756-1763.

Bokn, T.L., S.N. Murray, F.E. Moy and J.B. Magnusson. 1992. Changes in fucoid distribution and abundances in the inner Oslofjord, Norway: $1974-80$ versus 1988-90. Acta Phytogeogr. Suec. 78: 117-124.

Brandt, K.A.H. 1896. Das Vordringen mariner Thiere in den Kaiser Wilhelm-Canal. Zoologische Jbücher Abteilung Systematik 9: 387-408.

Brodie, J., C.A. Maggs, B.P. Society and D.M. John. 2007. The green seaweeds of Britain and Ireland. British Phycological Society, London, UK.

Burrows, E.M. 1959. Growth form and environment in Enteromorpha. J. Linn. Soc. 56: 204-206.

Burrows, E.M. 1991. Seaweeds of the British Isles: Chlorophyta. Natural History Museum Publications, London, UK. 
Dangeard, P. 1957. Faculte de regeneration et multiplication vegetative chez les Enteromorphes. Comptes Rendus Hebdomadaires Des Seances De L Academie Des Sciences 244: 2454-2457.

De Silva, M.W.R.N. and E.M. Burrows. 1973. An experimental assessment of the status of the species Enteromorpha intestinalis (L.) Link and Enteromorpha compressa (L.) Grev. J. Mar. Biol. Assoc. UK 53: 895-904.

Famà, P., B. Wysor, W.H.C.F. Kooistra and G.C. Zuccarello. 2002. Molecular phylogeny of the genus Caulerpa (Caulerpales, Chlorophyta) infered from chloroplast tufA gene. J. Phycol. 38: 1040-1050.

Gollasch, S. and H. Rosenthal. 2006. The world's busiest man-made waterway and biological invasions. In: (S. Gollasch, B.S. Galil and A.N.Cohen, eds) Bridging divides: maritime canals as invasion corridors. Springer, Dodrecht. pp. 5-90.

Hayden, H.S., J. Blomster, C.A. Maggs, P.C. Silva, M.J. Stanhope and J.R. Waaland. 2003. Linnaeus was right all along: Ulva and Enteromorpha are not distinct genera. Eur. J. Phycol. 38: 277-294.

Hinkelmann, A. and E. Schulz. 1899. Die Fische und sonstigen Nutztiere des Kaiser-Wilhelm-Kanals mit besonderer Berücksichtigung der Lebensverhältnisse des Herings. Die Heimat 9: 173-178.

Kornmann, P. and P.-H. Sahling. 1978. Die Blidingia-Arten von Helgoland (Ulvales, Chlorophyta). Helgol. Wiss. Meeres. 31: 391-413.

Leskinen, E., C. Alström-Rapaport and P. Pamilo. 2004. Phylogeographical structure, distribution and genetic variation of the green algae Ulva intestinalis and U. compressa (Chlorophyta) in the Baltic Sea area. Mol. Ecol. 13: 2257-2265.

Linnaeus, C. 1753. Species Plantarum, Exhibentes Plantas Rite Cognitas Ad Genera Relatas: Cum Differentiis Specificis, Nominibus Trivialibus, Synonymis Selectis, Locis Natalibus, Secundum Systema Sexuale Digestas. Trattner, Stockholm.

LLUR, Abteilung Gewässer. 2014. Nährstoffe in Gewässern Schleswig-Holsteins - Entwicklung und Bewirtschaftungsziele. In Schriftenreihe LLUR-SH Gewässer. LLUR, Flintbek, Germany.

Minchin, D., B.S. Galil, M. David, S. Gollasch and S. Olenin. 2006. Maritime canals as invasion corridors. In: (S. Gollasch, B.S. Galil and A.N. Cohen, eds) Bridging divides. Springer, Netherlands. pp. 1-4.

Mineur, F., M.P. Johnson and C.A. Maggs. 2008. Macroalgal introductions by hull fouling on recreational vessels: seaweeds and sailors. Environ. Manage. 42: 667-676.

Nielsen, R., A. Kristiansen, L. Mathiesen and H. Mathiesen. 1995. Distributional index of the benthic macroalgae of the Baltic Sea area. Acta Bot. Fennica 155: 1-55.

Nylander, J.A.A. 2004. MrModeltest v2. Program distributed by the author. Evolutionary Biology Centre, Uppsala University, Sweden.

Pollumaee, A., I. Kotta and J. Kotta. 2006. Port biological sampling as a tool for monitoring invasive species in high-risk areas of bioinvasions. Estonian Marine Institute, University of Tartu, Tallinn (Estonia). 14: pp. 35-41.

R Development Core Team. 2014. R: a language and environment for statistical computing. Retrieved from http://www.R-project.org/ (accessed 28 Feb 2018).

Reed, R.H. and G. Russell. 1978. Salinity fluctuations and their influence on bottle brush morphogenesis in Enteromorpha intestinalis (L) Link. Brit. Phycol. J. 13: 149-153.

Rönnbäck, P., N. Kautsky, L. Pihl, M. Troell, T. Soerqvist and H. Wennhage. 2007. Ecosystem goods and services from Swedish coastal habitats: identification, valuation, and implications of ecosystem shifts. Ambio 36: 534-544.
Saunders, G.W. and H. Kucera. 2010. An evaluation of $r b c L$, tufA, UPA, LSU and ITS as DNA barcode markers for the marine green macroalgae. Cryptogamie Algol. 31: 487-528.

Schories, D., U. Selig and H. Schubert. 2009. Species and synonym list of the German marine macroalgae based on historical and recent records. Meeresbiologische Beiträge, University Rostock, Germany.

Schueller, G.H. and A.F. Peters. 1994. Arrival of Fucus evanescens (Phaeophyceae) in Kiel Bight (Western Baltic). Bot. Mar. 37: 471-477.

Schütz, L. 1963. Ökologische Untersuchungen über die Benthosfauna im Nordostseekanal. I. Autökologie der sessilen Arten. Int. Rev. ges. Hydrobiol. Hydrogr. 48: 361-418.

Seebens, H., M.T. Gastner and B. Blasius. 2013. The risk of marine bioinvasion caused by global shipping. Ecol. Lett. 16: 782-790.

Simberloff, D. and M. Rejmanek. 2011. Encyclopedia of biological invasions. University of California Press, USA.

Stamatakis, A. 2014. RAxML version 8: a tool for phylogenetic analysis and post-analysis of large phylogenies. Bioinformatics 30: 1312-1313.

Tan, I.H., J. Blomster, G. Hansen, E. Leskinen, C.A. Maggs, D.G. Mann, H.J. Sluimam and M.J. Stanhope. 1999. Molecular phylogenetic evidence for a reversible morphogenetic switch controlling the gross morphology of two common genera of green seaweeds, Ulva and Enteromorpha. Mol. Biol. Evol. 16: 1011-1018.

Tournadre, J. 2014. Anthropogenic pressure on the open ocean: the growth of ship traffic revealed by altimeter data analysis. Geophys. Res. Lett. 41: 7924-7932.

Vogt, H. and W. Schramm. 1991. Conspicuous decline of Fucus in Kiel Bay (Western Baltic): what are the causes? Mar. Ecol. Prog. Ser. 69: 189-194.

Wikström, S.A., T. Von Wachenfeldt and L. Kautsky. 2002. Establishment of the exotic species Fucus evanescens C. Ag. (Phaeophyceae) in Oresund, Southern Sweden. Bot. Mar. 45: 510-517.

Wolf, M.A., K. Sciuto, C. Andreoli and I. Moro. 2012. Ulva (Chlorophyta, Ulvales) biodiversity in the North Adriatic Sea (Mediterranean, Italy): cryptic species and new introductions. J. Phycol. 48: 1510-1521.

Supplementary Material: The online version of this article offers supplementary material (https://doi.org/10.1515/bot-2018-0020).

\section{Bionotes}

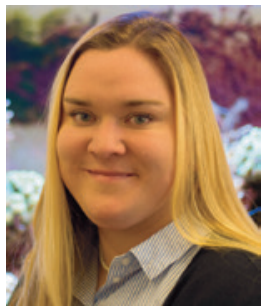

Sophie Steinhagen

Marine Ecology Department, GEOMAR Helmholtz Centre for Ocean Research Kiel, Düsternbrooker Weg 20, Kiel 24105 , Germany,

ssteinhagen@geomar.de

Sophie Steinhagen is a PhD student at the GEOMAR Helmholtz Centre for Ocean Research (Kiel, Germany) in the division of Marine Ecology. She holds a Master's degree in biology with a focus on marine botany from the Justus-Liebig-University Gießen 
(Germany), where she formerly investigated tertiary endosymbioses in amoeboid microalgae of the classes Chlorarachniophyceae and Synchromophyceae. Her current research addresses the taxonomy, molecular phylogeny and species delimitation of green seaweeds, particularly within the order Ulvales. She also investigates biodiversity and morphologic plasticity within the genus Ulva.

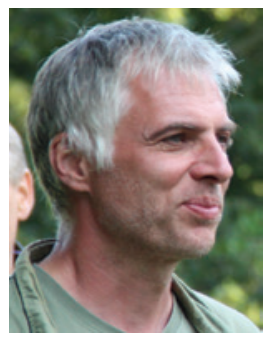

\section{Rolf Karez}

Environment and Rural Areas, State Agency for Agriculture, Schleswig-Holstein, Hamburger Chaussee 25, Flintbek 24220, Germany

Rolf Karez is a marine biologist with a focus on the ecology of seaweeds. He now works in an EPA in northern Germany as a scientific employee and is responsible for the monitoring of seaweeds and seagrasses and the assessment of seawater quality with respect to macroalgae. He also works with non-indigenous species in the North and Baltic Seas.

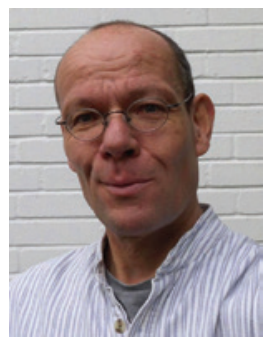

\section{Florian Weinberger}

Marine Ecology Department, GEOMAR Helmholtz Centre for Ocean Research Kiel, Düsternbrooker Weg 20, Kiel 24105, Germany

Florian Weinberger is a senior scientist at the GEOMAR Helmholtz Centre for Ocean Research (Kiel, Germany). His research focus is on the ecology of nuisance seaweeds, on the eco-evolutionary implications of seaweed invasions and on the microbiological and molecular biological aspects of seaweed and aquatic plant ecology. 